\title{
10th anniversary of SARS: China is better prepared for the H7N9 avian influenza outbreak
}

\author{
Yi Zhang, Yong-Sheng Yu, Zheng-Hao Tang, Xiao-Hua Chen, Guo-Qing Zang \\ Department of Infectious Diseases, Shanghai Sixth People's Hospital, Shanghai Jiao Tong University, Shanghai, \\ P. R. China
}

Key words: H7N9 avian influenza; SARS epidemic; public health; China

J Infect Dev Ctries 2013; 7(10):761-762. doi:10.3855/jidc.3850

(Received 12 June 2013 - Accepted 18 September 2013)

Copyright (C) 2013 Zhang et al. This is an open-access article distributed under the Creative Commons Attribution License, which permits unrestricted use, distribution, and reproduction in any medium, provided the original work is properly cited.

On March 31, 2013, the National Health and Family Planning Commission (NHFPC) of China announced that three cases of rapidly progressive pneumonia and respiratory failure, two in Shanghai municipality and one in Anhui province, were confirmed to be infected with a novel reassortant avian-origin influenza A (H7N9) virus [1]. As of May 27, NHFPC reported that avian influenza A (H7N9) had caused 37 deaths among 130 laboratory-confirmed cases in two municipalities and eight provinces of mainland China [2]. The threat of H7N9 avian influenza has reminded the Chinese public of the severe acute respiratory syndrome (SARS) outbreak that hit the country one decade ago. Many have wondered whether China's public health system is prepared for controlling the outbreak of H7N9 avian influenza.

In 2003, the SARS epidemic brought China to a standstill. The first cases of SARS were retrospectively identified in Guangdong province of southern China in November 2002. Then the infection spread rapidly within Guangdong and to other provinces and municipalities of China, including Beijing, which led to the largest local SARS epidemic of the world. The disease also spread rapidly from Hong Kong to other areas of the world, up to 29 countries and regions on five continents [3]. It is reported that 5327 cases with 349 deaths occurred in mainland China during the 2003 worldwide SARS epidemic, which accounted for $66 \%$ of all cases and $45 \%$ of all deaths respectively [3]. Furthermore, SARS had significantly negative impacts on China's economy. It is estimated that the SARS epidemic resulted in a total loss of US\$ 25.3 billion to China's economy and a 1-2\% drop in the growth rate of China's gross domestic product (GDP) in 2003 [4].

Obviously, the SARS crisis exposed serious deficiencies in China's public health system, which had been severely weakened by 20 years of relaxed government support and inadequate regulation in the health sector [5]. In the context of economic reform, the development of China's public health system lagged far behind its economic growth. Hence, the public health system was not well suited to making rapid and coordinated responses to public health emergencies. As a result, China lacked the ability to detect promptly, communicate responsibly and control effectively the SARS epidemic at the early stage.

On the positive side, however, the SARS crisis served as a wake-up call for China to recognize the importance of public health in socioeconomic development and the need to strengthen the government's leading role in public health [6]. Since then, public health has been top of China's public policy agenda and the level of government investment in public health infrastructure is unprecedented [6].

In the post-SARS era, China's infectious disease surveillance and reporting system has been significantly strengthened, which is one of the greatest lessons learned from the SARS epidemic. After the 2003 SARS epidemic, China has improved the disease surveillance system and built the largest networkbased disease reporting system of the world, namely China Information System for Disease Control and Prevention (CISDCP) [7]. China has also developed a surveillance and response system for pneumonia of 
unknown cause, which can provide national health authorities with early warning of the start of the influenza pandemic [7].

Furthermore, during the post-SARS period, China has established a comprehensive infectious disease prevention and control system, created a task force to combat avian influenza and set up hundreds of monitoring stations for avian influenza [8]. It is true that China responded to the H7N9 avian influenza outbreak with sound and effective strategies [9]. Additionally, the health sector was well-prepared and acted quickly, effectively and professionally [9]. On April 2, a third-level emergency response to influenza was initiated in Shanghai, where China's first two cases of avian influenza A (H7N9) virus infection in humans were reported. All hospitals there adopted the same precautionary measures during the SARS epidemic in 2003. And on April 6, the Shanghai municipal government suspended all farmers' markets with living poultry to prevent new human infections. China has won praise for rapid and wellhandled response to the outbreak of H7N9 avian influenza and exhibiting greater transparency in sharing disease-related information with the international community $[8,10]$. As of June 1 , only one human case of avian influenza A (H7N9) virus infection has been reported outside of mainland China [11]. Importantly, China has shared all the sequences of avian influenza A (H7N9) virus with the World Health Organization (WHO) and also shared the live virus with WHO and other laboratories, which has allowed scientists to trace the virus's origins, identify its mutations and develop crucial diagnostic tests [12]. Chinese scientists in collaboration with other researchers have used a ferret model to evaluate the infectivity and transmissibility of the virus [13]. There is no doubt that China has been in a much better position to handle another infectious disease outbreak like SARS.

In conclusion, China's response to the H7N9 avian influenza outbreak is next to exemplary [12]. Although a number of public health and food safety scandals have undermined the Chinese government's credibility in the last years, China's experience of fighting against H7N9 avian influenza can surely supply a model relevant to other developing countries.

\section{References}

1. World Health Organization (2013) Global Alert and Response (GAR). Human infection with influenza A (H7N9) virus in China. Available:http://www.who.int/csr/don/2013_04_01/en. Accessed 8 May 2013.

2. National Health and Family Planning Commission (2013) Epidemic information on human infection with avian influenza A (H7N9) virus during 20-27 May. Available: http://www.moh.gov.cn/yjb/s3578/201306/8f3a76c6a1524252 b2c094d8d15d0783.shtml. Accessed 2 June 2013.

3. Lam WK, Zhong NS, Tan WC (2003) Overview on SARS in Asia and the world. Respirology 8 Suppl: 2-5.

4. Hai W, Zhao Z, Wang J, Hou ZG (2004) The Short-term impact of SARS on the Chinese economy. Asian Econ Pap 3: 57-61.

5. Kaufman JA (2008) China's heath care system and avian influenza preparedness. J Infect Dis 197 Suppl 1: 7-13.

6. Liu Y (2004) China's public health-care system: facing the challenges. Bull World Health Organ 82: 532-538.

7. Wang L, Wang Y, Jin S, Wu Z, Chin DP, Koplan JP, Wilson ME (2008) Emergence and control of infectious diseases in China. Lancet 372: 1598-1605.

8. Hvistendahl M (2013) Influenza. A decade after SARS, China's flu response wins cautious praise. Science 340: 130.

9. National Health and Family Planning Commission (2013) Opening Statement. Available: http://www.moh.gov.cn/mohwsyjbgs/s3578/201304/b3d27fec 99b7423687f1e279aa7c619f.shtml. Accessed 8 May 2013.

10. Cohen J (2013) Influenza. New flu virus in China worries and confuses. Science 340: 129-130.

11. Chang SY, Lin PH, Tsai JC, Hung CC, Chang SC (2013) The first case of H7N9 influenza in Taiwan. Lancet 381: 1621.

12. Editors (2013) The fight against bird flu. Nature 496: 397.

13. Zhu H, Wang D, Kelvin DJ, Li L, Zheng Z, Yoon SW, Wong SS, Farooqui A, Wang J, Banner D, Chen R, Zheng R, Zhou J, Zhang Y, Hong W, Dong W, Cai Q, Roehrl MH, Huang SS, Kelvin AA, Yao T, Zhou B, Chen X, Leung GM, Poon LL, Webster RG, Webby RJ, Peiris JS, Guan Y, Shu Y (2013) Infectivity, transmission, and pathology of human-isolated H7N9 influenza virus in ferrets and pigs. Science 341: 183186.

\section{Corresponding author}

Guo-Qing Zang

Department of Infectious Diseases

Shanghai Sixth People's Hospital

Shanghai Jiao Tong University

600 Yishan Road, Shanghai 200233, P. R. China

Tel: + $862164369181-58673$

Fax: + 862124058384

E-mail: zangguoqin@126.com

Conflict of interests: No conflict of interests is declared. 